\title{
Civil Rights, Culture Wars, Voting and the Downfall of the Democratic Party in the South
}

\author{
James L. Baumgardner
}

Throughout much of its existence, the Democratic Party was heavily dependent upon the votes of the white South for its electoral success. In the last forty years, that situation has changed drastically. The erstwhile Democratic Solid South has been transformed into a Republican bastion. While many commentators still seek to explain this phenomenon in terms of race, white Southerners publicly are able to maintain political correctness by setting their change of political heart in a quite different context. This paper seeks to place the current political situation in the South in a historical context that explains how the racial issues that actually launched the downfall of the Democratic Party in that region became eclipsed by a national cultural conflict that has allowed an ever increasing number of white voters in the South to explain themselves in the transcending language of morality that comes so easily to Republicans rather than in the debasing context of race.

Almost from its inception in the 1790s as the Jeffersonian DemocraticRepublican Party, the Democratic Party was dependent upon the votes of white Southerners for its electoral success. Over the passage of time, the dependence grew, and, with the collapse of the Whig Party in the early 1850 s, the Democrats took virtually total control of southern politics. Their dominance rested first on the party's stout defense of the South's "peculiar institution" and then upon its post-Civil War role as the vehicle of white supremacy.

From the time white Southerners regained control of their own political destiny in the 1870s unti1 1948, the eleven former states of the Confederacy formed the so-called Solid South, delivering their electoral votes in election after election to the Democratic presidential candidate. ${ }^{1}$ The party's total control of southern state politics also meant that the eleven provided a solid and consistent large core around which any Democratic control of Congress was built. Without the South's political support, the national party's ability to control the federal government was virtually nil.

In the last three and a half decades of the 20th century, this situation increasingly changed. Total Democratic control of southern state governments has disappeared to the point that it has become virtually an anomaly, and, in those states in which it remains true, it is almost invariably due to local and state peculiarities. Particularly as it pertains to social and cultural issues, there is very little (if any) resemblance to the national party's stances.

JAMES L. BAUMGARDNER is professor of political science at Carson-Newman College.

The American Review of Politics, Vol. 25, Spring, 2004: 5-23

(C)2004 The American Review of Politics 
If anything, the decline of Democratic fortunes in the South is more obvious in relation to Congress, where southern white members of the party appear to be becoming an endangered species. This desperate state is reflected particularly in the Senate, the members of which must run statewide races. The present situation is such that, each time an incumbent Democratic senator faces re-election, he is presented with the options of conversion, not seeking another term, or confronting a grueling, no-holds-barred campaign in which anything goes.

Confronted with these options in 2004, five of the six incumbent Democrats up for re-election - in South Carolina, Florida, Georgia, Louisiana, and North Carolina - chose not to stand. Having witnessed the fate of his fellow Democratic incumbent in a nasty 2003 campaign, Georgia's Zell Miller not only chose not to run for another term but also increasingly began talking and acting like a Republican. Meanwhile, in North Carolina, some Republicans maintain that one of the reasons John Edwards decided to seek the Democratic nomination for president was that he knew that he could not win a 2004 bid for re-election to the Senate.

The situation in which the Democratic Party's plight in the South becomes most clearly and painfully obvious occurs in presidential election years. While George W. Bush's sweeping 2000 victory in the South came as a major blow to many Democrats, there certainly had been ample harbingers. Five-state southern victories for Barry M. Goldwater in 1964 and Richard M. Nixon in 1968 were followed by Nixon's sweep in 1972. Those southern Democrats who chose to believe that the 1972 outcome was due more to a poor choice by Democrats of their presidential nominee than to anything else undoubtedly were buoyed greatly by Jimmy Carter's near sweep of the South (losing only Virginia) in 1976. If they were, however, it could only have been so because they ignored the fact that more whites across the South as a whole had voted for Gerald Ford and that Carter's southern victory was made possible only by the overwhelming support of black voters.

The presidential elections of the 1980s should have served to reveal to southern Democrats the true nature of their precarious situation. Ronald Reagan's near sweep of the South in 1980 (losing only Carter's home state of Georgia) was followed in 1984 and 1988 by total Republican sweeps. Indeed, George W. Bush's triumph in 2000 was nearly an exact replication of his father's 1988 performance in the South in that George H.W. Bush received approximately 68 percent of the white vote but only 10 percent of black ballots. Subsequently, commentator Tom Wicker observed that the "white flight into the Republican Party, in all regions of the country but most spectacularly in the South, will be a palpable, continuing, virtually fatal problem for the Democrats as far ahead as a poll-taker can see" (Grantham 1998, 427). 
With economic issues at the forefront in both 1992 (a sagging economy) and 1996 (a robust economy), the Clinton-Gore ticket brought four southern states-Tennessee, Arkansas, Louisiana, and Georgia in the former and Florida replacing Georgia in the latter-back into the Democratic fold. Whatever encouragement southern Democrats may have taken by that turn of events, however, was blasted by Bush's crushing 2000 southern triumph. ${ }^{2}$

With Bush's stunning victory (no matter how besmirched by the way in which Florida finally fell into his camp), reality really began to dawn upon many observers of the Democratic situation in the South. There now are those who are arguing that the notion that the Democratic Party cannot win the presidency without carrying at least some southern states must be abandoned. The idea is not to give up on the South entirely but rather to acknowledge that, at least for the short haul, there is little hope that any Democratic presidential nominee (even one with southern roots) can pose a serious threat to the Republican grip upon most of the former states of the Confederacy. Interviews in the aftermath of the 2002 elections certainly seemed to confirm that idea in that only one in four southern white voters in those elections declared as a Democrat, while 53 percent affirmed a Republican identification (Welch 2003, 10A).

The argument for a Democratic presidential strategy centered upon non-southern states points both to the historical fact that the Republican Party for the larger part of its existence won elections based upon such a foundation and to the 2000 Gore performance in which he almost won despite the Republican sweep of the South, including his home state of Tennessee. In both New Hampshire and Ohio, the contest was quite close (despite the fact that Gore practically abandoned Ohio some time before the election), and Democratic victory in either one would have rendered the final outcome of the Florida vote moot.

While the 2000 census somewhat changed the configuration of the electoral vote, the strategy currently being urged upon the party by various individuals still rests upon a credible foundation. If a Democratic presidential nominee can hold the states carried by Gore and add Ohio to the mix (which certainly is not beyond the realm of possibility), there would be no need to carry any other state south of Maryland and east of the Mississippi River. Additionally, the party could start looking to the southwest. A growing Latino presence there not only could keep New Mexico in the Democratic camp but also could put Arizona and possibly Nevada and Colorado into play. Scooping such a coup could create a northeastern-mid-westernsouthwestern Democratic combination that easily would trump the Republican Dixie card. ${ }^{3}$

As heartening as this proposed scenario may be to national Democratic leaders and to any potential Democratic presidential nominee, it must sound 


\section{8 | James L. Baumgardner}

like political blasphemy to those Democrats who still have trouble imagining election of a Democratic president without the support of the South. What has brought Democratic fortunes in that region to such a low ebb that a section of the country that historically always had been a bulwark of support for the party now might have to be relegated (at least for the near future) to the dustbin of political history?

\section{The First Party System}

While the most obvious and easiest response to this question rests in the events of the past forty years or so, it could be argued that the seeds for the present woeful plight of the Democratic Party in the South actually were planted over 200 years ago in the so-called First Party System. The rivalry between Alexander Hamilton's followers, the Federalists, and those of Thomas Jefferson and James Madison, the Democratic-Republicans (or simply Republicans), arose during George Washington's first administration over the economic policies of Secretary of the Treasury Hamilton and the method of interpreting the Constitution in relation to those policies. The lines between the two parties hardened during Washington's second term over issues of foreign policy, specifically whether the American posture should tilt toward Great Britain (Hamilton) or France (Jefferson).

Viewing it as being inspired by the earlier American version, Republicans generally greeted the French Revolution and its leveling slogan of "Liberty, Equality, Fraternity" with enthusiasm, while the Federalists increasingly rejected it, especially after Great Britain was drawn into an opposing coalition. As the French revolutionary movement turned increasingly more radical and began to assume atheistic overtones, devout New England Federalists hastened to paint their French-admiring opponents with ungodly brush strokes, an effort that became almost frantic as the 1800 presidential election neared. Pious Americans were warned repeatedly that a Republican victory would result in the spread to this country of the worst of the French Revolution's chaotic and ungodly features. Jefferson himself was portrayed variously as an infidel, an unbeliever, an atheist, or, at best, a deist. Whatever he was, he possessed no respect for the Holy Bible, and his election would result in the removal from the schools of biblical instruction and the spread of immorality throughout the land (Cunningham 1971, 123124; Warren 1968, 37-38; Peterson 1973, 10). "Murder, robbery, rape, adultery, and incest will openly be taught and practiced," gravely warned one pious commentator (Peterson 1973, 10). According to a Massachusetts newspaper, the election of the "infidel Jefferson" would mean that "the seal of death is that moment set on our holy religion, our churches will be prostrated, and some infamous prostitute under the title of the Goddess of 
Reason, will preside in the Sanctuaries now devoted to the worship of the Most High" (Warren 1968, 37).

The Philadelphia-based Federalist mouthpiece, Gazette of the United States, repeatedly simplified the issue for its readers under "The Grand Question Stated," i.e. “... the only question to be asked by every American, laying his hand on his heart is "shall I continue in allegiance to GOD-AND A RELIGIOUS PRESIDENT; or impiously declare for JEFFERSONANO NO GOD!!!'” (Cunningham 1971, 124). In a portent of the future, the Republicans found themselves forced to the religious defensive, having to seek to reassure the country that they and their presidential candidate did not represent some kind of impious alternative to an opposition clothing itself in the garments of God-approved righteousness.

As would so often be true for the 20th century version of the party, economic issues proved the political salvation of Jefferson's party. While they helped place the fledgling country on its financial feet, Hamilton's policies directly benefited such small segments of the society [members of the socio-economic elite] that his party never developed a truly national following in the way that the agrarian-based Republicans did. Hence, the demise of the Federalists spelled national dominance for a party that in the early 1830 s, with the revival of two-party competition, dropped the Republican (or Democratic-Republican) label and became simply the Democrats.

\section{The Jacksonian Era}

Originating in the later 1820 s as the National Republicans but wearing economic garb more reminiscent of Hamilton than of Jefferson, the chief opposition to the Democrats by the mid-1830s had assumed the title "Whigs" to express its disgust with the increasingly autocratic behavior of the Democratic president whom they dubbed "King Andrew I." Also briefly appearing on the 1830 s American political stage was the first third party in American presidential history, the Anti-Masonic Party.

Whatever its differing political views of the Democrats, many adherents of both parties shared in common a moral disdain for those who were attracted to the Democratic banner by the party's emphasis upon equality (however theoretical) and individual rights. As had been true with the Jeffersonian version, the 1830s party model all too willingly (in the minds of their pious opponents) welcomed new immigrants with their Old World religious proclivities and behavior. In this case, it meant an increasing influx of Irish and Germans, a large number of whom were Roman Catholics whose faith did not appear to be restraining their immoral conduct. These people, as well as many other more established adherents to the Democratic cause, seemed all too inclined to drink, gamble, avoid church on Sunday, and engage in 
other forms of sinful activities. Simply stated, the Democrats were "the party of irreligion" (Holt 1973, 588).

To the Democrats, a person's personal moral conduct was none of the government's business and did not belong in the political arena. To an indeterminate number of Anti-Masons and Whigs (with the former often becoming the latter with their party's quick demise), such a loose attitude toward morality was totally unacceptable. Many leaders of the nation's founding generation had believed firmly in the concept of public virtue, i.e., that a republican form of government could succeed ultimately only if its citizens were willing to forego individual benefit in favor of the well-being of the society as a whole. To these 1830s-1840s moralists, such virtue could be cultivated only if individuals displayed that quality in their personal lives. To achieve this objective, they were open to the possibility of using the government to enforce morality. Found predominantly among northern Protestants of old-stock lineage, such people heavily influenced the nonsouthern version of Whiggery.

Fortunately for the Democratic Party, most citizens still embraced the concept of separation of church and state. Additionally, white Southerners were adverse to the use of the federal government to legislate morality for fear that attention focused today on some other version of immorality might tomorrow become riveted upon their "peculiar institution." Hence, an overweening emphasis upon socio-cultural issues in the national political arena did not develop in antebellum America, despite a proclivity of many nonsouthern moralists to push politics in that direction (Silbey 1984, 35-36; Foster 2002; McCormick 1986; Benson 1961; Vaughn 1983).

\section{Cultural Politics in the Post-Civil War Era Non-South}

The Republican Party was born in the mid-1850s garbed in the moral clothing of antislavery. While its garments were tainted by the racism inherent in the so-called free-soil position (i.e., a concern not for the victims of slavery but rather that the land be reserved for non-slaveholding whites to use), it had no trouble assuming the moral mantle dropped by the Whig Party as it passed from the national scene in the early 1850s. Indeed, having presided over a war that ultimately became viewed by many as a struggle for human freedom and championing the constitutional amendment that abolished slavery, it entered the Gilded Age (1870s-1890s) billing itself as the party of prosperity, patriotism (claiming a virtual lock on this virtue as the defender of the Union during the Civil War while portraying the Democrats as having engaged in treasonous activity), and morality. So impressed was the party with itself that it took to identifying itself in the 1880s as the Grand Old Party (GOP). 
For many old-stock Protestants (often characterized by the acronym WASPs, white Anglo-Saxon Protestants), the Gilded Age was a troubling time. The era was one of both economic and cultural transition. The nation's economy was moving rapidly from an agrarian-based, producer-oriented one to an industrial, consumer-oriented one with an emphasis upon acquisition of material goods, a disturbing trend to pious people even as they participated in it.

Traditional American culture began to experience shock as the areas of origin of an increasing number of immigrants shifted from the original ones of the British Isles and northern and western Europe to the heretofore largely unknown ones of southern and eastern Europe. In the early 1880s, this wave became the predominant one, bringing with it people of a bewildering variety of ethnic backgrounds, cultures, and religious experiences. As American society became increasingly diverse and pluralistic, many WASPs began to sense that what they considered the American way of life was becoming endangered. Hence, they developed an interest in such issues as immigration restriction, English-only public schools in which Bible reading was to be done only from the King James Version, Sunday-closing laws (so-called Blue Laws), and, above all, prohibition.

Ultimately climaxing in the adoption of the Eighteenth Amendment, the drive to curtail the production, transportation, and sale of alcoholic beverages was viewed by many of its proponents as a means of controlling the rowdy behavior of many of the nation's newcomers who had brought with them their Old World drinking habit. Control this habit, and the result would be a more orderly, moral society.

Faithful church-goers, the WASPs tended to belong to sects that today are described as evangelical and which had a broad definition of what constituted sin, denominations such as Presbyterian, Methodist, Baptist, Congregational, and certain varieties of Lutheranism. Such individuals had the attitude that, if people were not moral enough to choose the right on their own, the state should help in instilling in them virtue. Seeking a political ally, they quickly realized that the major party most likely to become their willing partner in this effort was the one that many of them by now were regarding as the party of piety or the party of the community. As they viewed politics, the only godly alternative was to support and vote for the party whose acronym might well be interpreted to mean "God's Own Party." Hence, the GOP acquired some of its most loyal supporters during the Gilded Age for sociocultural reasons. A century and more later, history would repeat itself.

As the foregoing discussion of Gilded Age politics suggests, a key factor in determining political identification outside the South was ethnic and religious background. Both many people of long-time residency in the country and numerous newcomers were affiliated with religious groups- 


\section{2 | James L. Baumgardner}

Catholic, Episcopalian, certain kinds of Lutheranism - that tended to be more restrictive in their view of what constituted sin and believed that definitions of acceptable moral conduct should be left to the church to determine. (As Jews began entering the country in considerable numbers for the first time, they took the same view from the standpoint of their religious orientation.) For such people, deciding between Democrats and Republicans was a "no brainer." Since the choice on social and cultural issues lay between a party predisposed to allow the government to play a role in defining morality and one that traditionally had believed that personal moral conduct was none of the state's business, they opted for the party of personal liberty (or, of the individual), or, as those on the other side implicitly viewed it, the party of immorality. Thus, in the view of many devout northern WASPs, it was the sinners and the less devout who kept the Democratic Party competitive in the North, at least in the urban areas (Cherny 1997; Miller 2002; Kleppner 1982). A century or more later so-called New Evangelicals would come to the same view regarding the nation as a whole.

\section{Cultural and Racial Politics in the Post-Civil War South}

White Southerners ethnically and religiously were very much akin to those northern WASPs who voted consistently Republican. Their ethnic composition was little changed from that of the antebellum South (or, for that matter, from the Seventeenth and Eighteenth Centuries). Religiously, Baptists, Methodists, and Presbyterians overwhelmingly called the denominational rolls in the South. Further, white Southerners in the Gilded Age were undergoing a change of heart about the use of the state to legislate morality. Before the war, they agreed with the national Democratic Party's emphasis on laissez faire in regard to social and cultural issues because they did not wish to trigger a national debate about the morality of slavery. With that institution no longer an issue but with control of the former slaves very much on their minds, they now began to have second thoughts about nongovernmental involvement in private conduct.

Prohibition was the cutting-edge social issue for many white Southerners. Envisioning drunken freedmen unable to practice self-restraint and thus becoming a threat to public and private safety, southern whites got behind the national push by pious people to prohibit the production, transportation, and sale of alcoholic beverages. Indeed, one historian has gone so far as to suggest that it was the ultimate success of this drive that helped create the South's identification as the Bible Belt, the "stronghold of religion in policies and a bastion of support for moral legislation" (Foster 2002, 228). ${ }^{4}$

Given the obvious similarity to their northern counterparts on the issue of moral legislation, why were white Southerners not voting for the party of 
piety? Simply stated, as the South once had been the bastion of slavery, it now was the stronghold of white supremacy. Like a number of their northern brethren, no "respectable" white Southerner was prepared to accept black equality. Yet, that precisely is what elements of the Republican Party had attempted to foist on the South during the Reconstruction Era. Only resolute resistance by the section's white population had prevented this drive's success. Yet, as late as 1890, some perverse Republican members of the House of Representatives sought to defend black voting rights by pushing through that body a bill to that end. Only determined opposition by Senate Democrats assured the measure's defeat (Metler 2002). Shortly afterward, the southern states launched efforts that by the early 20th century effectively had killed black voting in the region and had relegated black Southerners to the status of second-class citizens.

Efforts to impose proper moral conduct upon the South's former slaves was one thing. Attempts to give them equal standing through civil and voting rights legislation was quite another! Hence, southern whites rallied behind their version of the Democratic Party, a variety that had upheld slavery before the war and which became the dedicated defender of white supremacy during the Glided Age. Thus emerged the Solid South, voting consistently Democratic in election after election through the remainder of the 19th century and well into the 20th.

At the same time, devout white Southerners were able to make the party on the sectional level function like the Republican Party often did on the non-southern level when it came to moral legislation, i.e., as the party of piety. In that manner, southern whites were left free to act both as racists and as moralists, and the erstwhile party of personal liberty was their vehicle to promote both. To consider voting Republican was an unimaginable thought to whites in most parts of the South.

\section{Civil Rights and Racial Politics}

1948 should have served as something of an early warning for Democrats who could not imagine political life without the support of the South as to what could shake the seemingly solid foundation of their backing in that region. When liberal Democrats managed to have a strong civil rights plank inserted into the national party's platform, the reaction of a number of southern Democrats was immediate. In a manner reminiscent of their 1860 forebearers, they bolted the party and formed a southern version. Taking the official title States' Rights Democrats but quickly dubbed the Dixiecrats, they nominated as their presidential candidate the governor of South Carolina, Strom Thurmond, who in the election carried four Deep South states (South Carolina, Alabama, Mississippi, and Louisiana). Although resolute 
opposition by southern Democratic members of Congress prevented the subsequent passage of a civil rights measure by the Democratic-controlled Congress elected in 1948, the election nonetheless sounded the death knell of the Democratic Solid South on the presidential level, as no party nominee has swept the former states of the Confederacy since that time.

For those who view race relations as the core issue accounting for the decline of Democratic fortunes in the South, the decisive point in time is easy to locate. It came when a southern Democratic presidential cowboy from Texas decided to revive the civil rights bill that had been pushed on the congressional docket by his Massachusetts Yankee predecessor but which had been going nowhere. Riding a wave of national sympathy generated by the untimely and unseemly death of John F. Kennedy, Lyndon B. Johnson used a combination of liberal Democrats and moderate Republicans (the latter of a stripe that now is nearly extinct on the congressional level) to propel into law the Civil Rights Act of 1964, the most sweeping measure of its kind in American history. Subsequent resolute support of that measure by a federal court system that already had been moving in that area and by federal authorities eventually would earn for the South the distinction of being the most integrated section of the country, but Johnson well knew what the political consequences would be. On his way to Texas after having signed the bill into law, he confided to aides, "I think we just gave the South to the Republicans." Bill Moyers, then a close associate of LBJ, remembered later that he had remarked that it would be "for your lifetime and mine" (Branch 1998, 404).

As Johnson had anticipated, a political flare of the coming exit of white Southerners from the national Democratic Party was fired in the 1964 presidential election. The Republican nominee, Senator Barry M. Goldwater of Arizona, proved to be too far right of the nation's political mainstream to represent a real threat to Johnson's bid for election to the presidency in his own right. He had voted against the Civil Rights Act, however, and, of the six states he carried, five were located in the Deep South.

As if determined to assure that southern defections would continue, Johnson had begun thinking even before the election of a measure he wanted to push through Congress in 1965. Accordingly, he gave his instructions to Attorney General Nicholas Katzenbach: "I want you to write me the goddamnest, toughest voting rights act that you can devise" (Miller 1980, 371). The result was the Voting Rights Act of 1965, which for the first time put real legal teeth into the Fifteenth Amendment as far as potential southern black voters were concerned. In the aftermath of its passage by the liberal Democratic-dominated Congress elected in the 1964 elections, African Americans became a true political force in the South. The measure also made them the bulwark of the southern wing of the Democratic Party, as 
white flight from it accelerated thereafter. However integrated the South might become in other areas, non-integration of the franchise would become the key to understanding southern politics after the 1960s.

By remaining true to the southern version of politics, southern Democrats initially were able to confine the bleeding to the presidential level. As the party's congressional incumbents gradually left politics in one way or another from the 1970s onward, however, they increasingly became likely to be replaced by Republicans. By the 1990s, that process had spread to the lower levels of government in many southern states.

\section{Culture Wars and Southern White Racial Redemption}

Would this pattern have developed if race relations had remained a central issue after the 1960s rather than receding into the background as it has in most places in the South? Would the Democrats have been able to remain competitive in southern politics despite their strong identification with black civil and voting rights? Certainly, white Southerners are much more at ease with such social and economic integration as presently exists in the region than they once were, perhaps in no small measure due to the fact that residential patterns that have established themselves over the last three decades or so have allowed for a gradual re-segregation of public schools in many areas. Born long after the battles of the 1960s, some members of the increasingly conservative generation of white students currently populating the South's college and university campuses hasten to assure any instructor who might bring up the issue of increasing white support for the Republican Party in the South that it has nothing to do with race. In the same vein, Southerners who feel strongly about the display of the Confederate flag take umbrage at the suggestion that it has anything to do with anything other than pride in the southern heritage.

Shortly after Howard Dean's briefly famous remark about the need of the Democratic Party to re-connect with white southern male voters with Confederate flags in their pickup trucks, one such individual carefully explained to a national television news audience the problem. Standing with his pickup truck into the paint job of which was interwoven in sweeping colors the banner in question, he declared that he once had voted for the Democrats but no more could do so because they seem not to be for "the people" but for "the minority" (NBC 2003). ${ }^{5}$

In the minds of many white Southerners, agreement with such an assessment definitely would not be racially motivated because, in their thinking, social and cultural issues and not racial views determine their political preferences. Hence, there is no need to speculate about the reason for their unwillingness to support the Democratic cause or which party they 
might be supporting under different circumstances. As particularly the more religiously devout among them view it, it is not a matter of race but rather of morality and which of the two major parties stands for decency and right living. In the culture wars, the only thing that matters is which party stands for "the people" and not for "the minority."

The liberalization of standards of speech and press, the "outing" of homosexuals, the rise of feminism, and the increasing diversification of the national society due to a new influx of peoples from Latin America, Asia, and elsewhere made the last three decades of the 20th century as bewildering for white Christian (both Protestant and Catholic) old-stock Americans as events of the Gilded Age had been for WASPs. Emotion-laden issues such as abortion, homosexuality/gay rights, disintegration of the family, pornography, gun control, capital punishment, the teaching of "secular humanism" (usually revolving around the topics of evolution and sex education) in public schools and the removal of God from them (in the form of banning officially orchestrated Bible reading and prayer) raced to the top of their agenda as concerns in the 1970s and 1980s. (Now, there has arisen the issue of gay marriage and civil unions.) In some areas where the influx of Hispanics and Asians was the heaviest, the old issue of English-only public schools reappeared.

To fight the culture wars, a so-called New Right appeared in the 1970s, soon given spiritual backbone by the appearance of the Religious Right/ Christian Right/Moral Majority. Strongly patriotic, these groups pressed for a restoration of morality in government, which then could be used as an instrument to help bring about the nation's spiritual regeneration, as well as to promote righteousness abroad.

In this culturally charged environment that has evolved over the past three decades or so, it may be argued that the real division in American politics has little to do with race, class, or gender and much more to do with the gap that has opened between the spiritualists and the secularists in our society. The fault line along which the nation's political life now may be said to run is the so-called culture wars. On the one side of that line are the secularists (those in whose lives religion plays no, little, or only a nominal role), plus those Christians and others to whom social justice and peaceful relations with the rest of the world are a top priority. On the other side are those religiously committed to creating their version of a righteous America, one that puts an end to a wide variety of sinful behaviors they believe is threatening the moral fiber of the nation.

Along that line, political polarization of a type unprecedented in the nation's history steadily has been taking place, reducing the numbers of voters serving as a swing between the two major parties (Leo 2003, 66). As a result, there is developing within the electorate hard lines of political identification unseen since the Gilded Age. 
Belonging to evangelical-type churches of a kind (although not necessarily the same denominations) that their Gilded Age forebears attended, predominantly white, conservative, religiously committed people increasingly are to be found in the ranks of the Republican Party. In the 2000 presidential election, they provided George Bush with 40 percent of his popular vote (Tolson 2003, 41).

In no region of the country are these "New Evangelicals" as strong as they are in the nation's historical Bible Belt, the South. Sunday after Sunday, they flock to theologically conservative churches to sing songs of God and country (with "God Bless Our Troops" currently being a favorite among some) and to hear their pastors or guest speakers present biblically-based commentaries on current social issues which are reflected in stances taken in the Republican party platform and/or are contrary to positions set forth in the Democratic counterpart. During election years, especially presidential ones, they frequently are steered to so-called voter guides that purport to take no stance as for whom the faithful should vote but which present the contrasts in stances of Democratic and Republican candidates on key social issues in such a stark and simplistic (sometimes exaggerated) form as to leave no doubt about which party has the truly God-fearing candidates. For such people, there is little doubt as to how the GOP acronym could be translated into words.

\section{The Role of the Southern Baptist Convention}

No well-established Christian body in the Bible Belt encourages this theological and political conservatism better than does the group organized as the Southern Baptist Convention, the single largest non-Catholic Christian denomination in the country. Born supporting slavery and raised on a steady diet of racial segregation, this body had among its supporters mostly people who had established a comfortable political home in the southern version of the Democratic Party. Then came the shock of the civil rights movement of the 1950s and 1960s and the sacrifice of their concerns by the party's notional leadership.

Before they could adjust to the racial jolt, the culture wars burst upon them. Coincidentally, the Convention was shaken by a takeover of it by its most conservative elements, the so-called Fundamentalists. Begun at the end of the 1970s and largely completed within a decade, this religious seizure of power brought to the forefront spiritual counterparts to the cultural conservatives who increasingly were controlling the Republican Party. A fusing of their interests was inevitable.

Early in the Fundamentalist takeover of the SBC, the leadership withdrew the Convention from the Baptist Joint Committee on Public Affairs, 
primarily because the latter took the notion of separation of church and state too literally (and too much in line with the historical Baptist position on that topic). In place of membership in this body, an independent Ethics and Religious Liberty Commission was created to reflect more accurately the notion that there were issues upon which there should be a mingling of church and state in order to establish the proper moral stances to guide the nation toward true righteousness.

To forestall criticism and comparison of the SBC's past stands on cultural issues related to race relations with its present hard-line views on such things as abortion, homosexuality, and gender relations, the Convention has asked forgiveness for the past sins committed by the great bulk of its churches in relation first to slavery and then segregation. "During the heated debates over integration in the 1950s and 1960s, many of our churches were ignorant of just how captive they were to a culture of racial oppression," confessed an October, 2003 article in SBC Life, the Convention's official print media voice.

The main purpose of the article, however, was established in its title, "The Folly of Racism, Then; Of Sexual Liberation, Now." Ingeniously, an apology for a past defense of segregation was converted into an attack upon the nomination of an Episcopal homosexual clergyman to be a bishop. Declaring that the Will and Grace culture endorsed such a move as fully as the Amos and Andy culture had accepted white supremacy, the conclusion was obvious, "...the churches of Jesus Christ must stand against the white sheets of the Ku Klux Klan and against the rainbow flags of the Gay Liberation Front, because both represent the cultural captivity of the church" (Moore 2003, 9). ${ }^{6}$

It is obvious to which of the two major parties the leadership of the SBC is looking to help not only the churches but American traditional culture stand against not only the flag of homosexuality but also the banners of abortion, secular humanism, and all other perceived threats to traditional family values, as well as those forces believed to threaten the nation's security or question its motives abroad. In the latter vein, the SBC represents the only denomination to not only place its official stamp of approval upon the war with Iraq but also to provide theological justification of it by explaining how it met the standards of a just war. Gathered in their 2003 annual convention in June, Southern Baptist church messengers adopted a resolution that "endorsed U.S. military action in Iraq as a "warranted action based upon the historic principles of just war"” (Strode 2003, 7).

Turning to cultural issues, another resolution passed by this same body reflected the Republican platform's no abortion stance by reiterating "the SBC's opposition to the Supreme Court's Roe vs. Wade decision legalizing abortion" and expressing "regret that previous actions had supported 
abortion" (a reference to resolutions of the Convention in 1971 and 1974before the Fundamentalist takeover-that had recognized that abortion should be legally permissible in cases of "rape, incest, clear evidence of severe fetal deformity, and carefully ascertained evidence of the likelihood of danger to the emotional , mental, and physical health of the mother"). Anticipating an issue that Republican strategists obviously hope will become a decisive one in the 2004 presidential campaign, another resolution "restated opposition to the legalization of same-sex marriage." Finally, in line with the family values theme that Republicans have made their own, the messengers "renewed Southern Baptists' commitment to the biblical model of the family and the permanence of marriage" (Strode 2003, 7). In the same vein, the convention leadership later could not resist taking a swipe at those 2004 Democratic presidential hopefuls who had expressed opposition to a constitutional amendment in defense of traditional marriage (Faust 2004, 11).

\section{The Democratic Dilemma}

Obviously, the culture wars that were launched in the 1970s and continue unabated to this day offer a tremendous, if not virtually overwhelming, challenge to a party that has held, virtually since the 1790 s, to the belief that government has no business attempting to legislate morality in relation to social and cultural issues that do not involve criminalized activities. As emotional as past struggles over what constitutes proper personal moral conduct may have been, they appear to have been nothing in the thinking of those who are locked in bitter conflict over issues such as abortion, homosexuality/gay rights, gun control, so-called secular humanism, and family values. The problem for Democrats, as one syndicated columnist has noted, is as follows: "We end up with religious debates about abortion or gay marriage or the Ten Commandments in the courthouse. But we don't have a moral vocabulary for discussing poverty or jobs or education" (Goodman 2004, 85). Lacking that language, the so-called secularists who control the national party councils must seek to find those who stand on their side of the culture wars' fault line and to join them with those whose primary concerns are focused on something other than "God, guns and gays."

Unfortunately for southern supporters of the Democratic Party, such a combination is not likely to be found throughout most of their region. That being the case, how are their candidates to survive the Republican determination to feed the southern white electorate a steady diet of "God, guns, and gays," a propensity that now has been accentuated by the more recent demands of some devout cultural warriors that the Ten Commandments be posted in schools and other public places and that local and state governing 
bodies adopt a resolution acknowledging God as the foundation of our national heritage and government? The answer likely is one thing on the presidential level and quite another on the congressional and state levels.

On the congressional and state levels, at least a few southern Democrats have decided to adopt the old adage of "if you can't lick 'em, join 'em." The idea is not to convert but to mimic. Campaigning in 2002 for a vacant congressional seat in a district slightly weighted in favor of the Republicans, veteran Democratic state legislator Lincoln Davis vowed that "no one will out-gun, out-God, or out-family me." He won the race, garnering the endorsement not only of the United Auto Workers but also of such normally Republican-leaning organizations as the Tennessee Conservative Union, National Rifle Association, and the National Right to Life. ${ }^{7}$ Democrat Kathleen Blanco won the Louisiana governorship in 2003 on the basis of a determined campaign in which Republicans were unable to separate her from stances on social and cultural issues indistinguishable from their own. She even went so far as to flirt with the idea of creationism (Schecter and Teixeira 2004, 28)! White Democrats willing to resort to similar tactics stand at least a decent chance of survival on the congressional and state levels through much of the South, otherwise, they do not.

On the presidential level, the answer to the question of survival is much more problematic, particularly in light of the reality that persons seeking the party's nomination have had great difficulty articulating religious concerns, regardless of the depth of their personal convictions. Even a southern-born prospect such as John Edwards is much more animated while discussing other topics. Most of them are like John Kerry, who tends to be "more at ease talking policy then morality" (Goodman 2004, 85). While this problem historically comes with being a dedicated member of the party of persona1 liberty, the net result is that God is left as the exclusive property of the party of piety, the Republicans, who are willing to invoke His name for a wide variety of reasons ranging from national defense to all kinds of social and cultural issues.

\section{Conclusion}

Kevin Phillips has observed that the racial and cultural appeal of the Republican Party in the states of Texas, Mississippi, Alabama, Georgia, South Carolina, and Virginia (to which one perhaps might add North Carolina) is so strong that its hold on presidential politics in those states is not likely to be broken in the foreseeable future. Given the right economic circumstances, this situation leaves in potential play the states of Tennessee, Arkansas, Louisiana, and Florida. The state of the economy in the first three is such that, under certain conditions and with the right candidate, they 
might fall back into the Democratic camp in the way they did for the 1990s Clinton-Gore ticket. Florida, with its population of seniors concerned about Social Security and Medicare and its growing number of non-Cuban Hispanics concerned about economic matters, also is not out of the question (Phillips 2004, 27).

Achieving victory in any southern state, however, must take into account the radical polarization of the electorate. African Americans in the South certainly share many of the social and cultural concerns of their white counterparts. Still, poverty, poor employment opportunities, under-funded schools, and inadequate housing and health care are issues of far greater concern in many of their communities. Having made such progress as they have through Democratic-sponsored legislation, they have little reason to look to the Republican Party, but the problem for Democrats in any given election is the percentage of their turnout at the polls. It benefits Democratic presidential candidates little if they receive 90 percent plus of the black vote in less than a heavy turnout.

Even if Democrats get that heavy minority turnout, they still must receive at least 40 percent of the white vote in order to win in the South. By contrast, a 60 percent plus white vote for the Republican Party likely gives their candidate a victory. In the face of that reality, perhaps the best advice for the Democrats for at least the near future is as follows, "Run like every state is Ohio, pursue opportunities in the South selectively as they arise and let southern Democrats be southern Democrats" (Schecter and Teixeira 2004, 28).

For Democrats, one thing is certain, i.e., the Solid South is history as far as their party is concerned. They need to become adjusted to that political reality and learn to live with it. Like the Republicans for so many decades of their history, perhaps they will discover that there is political life without the South.

\section{NOTES}

\footnotetext{
${ }^{1}$ The only cracks in the Solid South prior to 1948 appeared in the presidential elections of 1920 and 1928. In the former, Tennessee deserted, and, in the latter, it was joined by North Carolina, Virginia, and Florida.

${ }^{2} \mathrm{~A}$ well-known syndicated conservative columnist placed the entire subject of presidential elections in the South over the past thirty-two years in a clear perspective by noting that, in such contests from 1968 to 2000, the former Confederate states (complemented by Kentucky and Oklahoma) cast a total electoral vote of 1385 , of which the various Democratic nominees received only 270, or 20 percent (Will 2003, 6A).

${ }^{3}$ The concept of a non-Southern Democratic strategy has been set forth in various publication settings since 2000. Examples: Judis and Teixeira (2002); Greenberg (2004); Schaller (2003); Velasquez and Cobble (2004); Schecter and Teixeira (2004).
} 


\section{2 | James L. Baumgardner}

${ }^{4}$ Spain (1967) set forth the classic study of the role of one southern denomination in bringing about this transition.

${ }^{5}$ This interview occurred the day following Republican gubernatorial victories in Kentucky and Mississippi.

${ }^{6} \mathrm{~A}$ more recent line being developed pictures the SBC as en early champion of the civil rights movement (Moore 2004). Ironically, while it is true that the SBC in its annual gatherings early did adopt resolutions condemning segregation (which totally were ignored by most of its churches and their pastors), the people taking the lead in doing so now are condemned by the present leadership as having been "liberals" not possessing a true view of God's word. They and/or their spiritual descendants either have been silenced or driven from the SBC.

${ }^{7}$ The author personally called Representative Davis' congressional office, which kindly provided him with an e-mail message containing both the quote and a list of endorsements, as well as other information. The district in question is Tennessee's Fourth.

\section{REFERENCES}

Benson, Lee. 1961. The Concept of Jacksonian Democracy: New York as a Test Case. Princeton: Princeton University Press.

Branch, Taylor. 1998. Pillar of Fire: America in the King Years, 1963-68. New York: Simon \& Schuster.

Cherney, Robert W. 1997. American Politics in the Gilded Age, 1868-1900. Wheeling, IL: Harlan Davidson.

Cunningham, Jr., Noble E. 1971. The Election of 1800. In History of American Presidential Elections, 1789-1968, I: 1789-1844, eds. Arthur M. Schlesinger, Jr. and Fred L. Israel. New York: Chelsea House.

Foster, Gaines M. 2002. Moral Reconstruction: Christian Lobbyists and the Federal Legislation of Morality, 1865-1920. Chapel Hill: University of North Carolina Press.

Foust, Michael. 2004. Backlash Against the Massachusetts Ruling. SBC Life, February/ March.

Goodman, Ellen. 2004. Will Liberals Get Religion? Knoxville News-Sentinel, January 22.

Greenberg, Stanley B. 2004. The Two Americas: Our Current Political Deadlock and How to Break It. New York: Thomas Dunne Books.

Holt, Michael F. 1973. The Antimasonic and Know Nothing Parties. In History of U.S. Political Parties, I.1789-1860, ed. Arthur M. Schlesinger, Jr. New York: Chelsea House Publishers.

Judis, John B., and Ruy Teixeira. 2002. The Emerging Democratic Majority. New York: Scribner.

Kleppner, Paul. 1982. Who Voted?: The Dynamics of Electoral Turnout, 1870-1980. New York: Praeger Publishers.

Leo, John. 2003. Splitting Society, Not Hairs. U.S. News \& World Report, December 15.

McCormick, Richard L. 1986. The Party Period and Public Policy: American Politics from the Age of Jackson to the Progressive Era. New York: Oxford University Press.

Miller, Merle. 1980. Lyndon: An Oral Biography. New York: G.P. Putnam's Sons. 
Miller, Worth Robert. 2002. The Lost World of Gilded Age Politics. The Journal of Gilded Age and Progressive Era 1:49-67.

Moore, Ronald D. 2003. The Folly of Racism, Then; Of Sexual Liberation, Now. SBC Life, October.

Moore, Ronald D. 2003. Revivalism, Civil Rights, and Same-Sex "Marriage." SBC Life, May.

NBC Evening News, November 5, 2003.

Peterson, Merrill D. 1973. The Election of 1800. Crucial American Elections. Philadelphia: American Philosophical Society.

Phillips, Kevin. 2004. All Eyes on Dixie. The South Isn't Bob Jones University and Democrats Can Make Inroads There. The American Prospect, February.

Schaller, Thomas F. 2003. Forget the South: A Democratic Strategy for 2004 that Bypasses Dixie. The Washington Post National Weekly Edition, November 24-30.

Schecter, Cliff, and Ruy Teixeira. 2004. All Eyes on Dixie Perhaps. But Democrats on the Hunt for Electoral Votes Should Look to Ohio. The American Prospect, February.

Silbey, Joel H. 1984. The Salt of the Nation: Political Parties in Ante-Bellum America. In Political Parties and the Modern State, ed. Richard L. McCormick. New Brunswick, NJ: Rutgers University Press.

Spain, Rufus B. 1967. At Ease in Zion: Social History of Southern Baptists, 1865-1900. Nashville, TN: Vanderbilt University Press.

Strode, Tom. 2003, Resolutions Wrap Up. SBC Life, August.

Tolson, Jay. 2003. The New Old-Time Religion. U.S. News \& World Report. December 8.

Vaughn, William Preston. 1983. The Antimasonic Party. Lexington: The University Press of Kentucky.

Velasquez, Joe, and Steve Cobble. 2004. Blue States, Latino Voters. The Nation, January 5.

Warren, Stanley. 1968. The Battle for the Presidency. New York: J.B. Lippincott Company.

Welch, William M. 2003. Dean Dispute Puts Focus on Dems' Lag in the South. USA Today, November 7.

Will, George. 2003. A Look at the Democratic Charge of Bush Unilateralism. The Oak Ridger, December 11. 
